\title{
Responding to climate change: Australian tourism industry perspectives on current challenges and future directions
}

\begin{abstract}
Like other destinations in the Asia Pacific region, Australia's tourism industry is vulnerable to the impacts and implications of climate change. The country's reliance on its natural product which is potentially under threat, coupled with the potential for changing consumer demand patterns, particularly in long-haul markets, should be concerning for the tourism industry. Yet, the tourism industry has been criticised for its short-term, profit orientation and lack of action regarding climate change (Hall \& Higham, 2005; Jenkins \& Nicholls, 2010; Viner, 2006). However, little empirical research has investigated the tourism industry's perspectives regarding climate change, neither the relative importance of climate change vis-à-vis other challenges facing the sector, or, the strategies and actions required by the tourism industry to facilitate adaptation and mitigation strategies. It is against this background that a qualitative study was undertaken with expert representatives from both the public and private sectors of Australia's tourism industry to explore the industry's perspectives on current challenges and future directions with regards to climate change. The findings show that while the industry is aware of the importance of climate change, it is not seen as a pressing issue, particularly in light of the global economic crisis, and there has been little action by the industry in response to climate change. Respondents noted that the tourism industry is largely relying on, and waiting for, government intervention and leadership for the sector with regards to climate change.
\end{abstract}




\section{Introduction}

Climate change is arguably a significant issue facing the tourism industry, with wide-ranging policy and practice implications for both the public and private sectors. Tourism has been described by the World Tourism Organization (UNWTO) as both a 'victim' and a 'vector' of climate change. This is because environmental or climatic changes not only impact upon tourist demand for certain destinations, but the supply of tourism, air travel in particular, is an often cited contributor to climate change. Concomitantly, 880 million international travellers in 2009 spending some US\$852 billion (UNWTO, 2010), highlights the continuing economic, environmental and social magnitude of the global tourism industry. Indeed, tourism is a key economic sector for many countries around the world. In the Asia Pacific region, in particular, tourism has become a significant source of foreign exchange revenues for many countries, including some of the least developed countries and island developing nations within the region (United Nations Economic and Social Commission for Asia and the Pacific [UNESCAP], 2007). Yet tourism is potentially threatened by sea level rise, coral bleaching, water supply restrictions, changing rainfall patterns, greater dry season severity and higher summer temperatures, as well as increased frequency and severity of storms, cyclones, floods, fires and droughts (Craig-Smith \& Ruhanen, 2005; Intergovernmental Panel on Climate Change [IPCC], 2007a; Steffen, 2009; UNWTO, 2007); impacts that threaten one of the fastest growing regions in the world, and a region where tourism is often employed as a poverty alleviation strategy for developing countries.

In Australia, tourism plays a vital role in the Australian economy. With 5.5 million international visitors in 2009 and a substantially larger domestic market, Australia's tourism product is largely based on its natural attractions and the country's favourable 
temperatures are a major part of its appeal to key source markets. However, as the environment and climatic conditions of a destination are often the key attractions and basic resource for tourism, adverse climatic conditions can seriously harm tourism operations and the sustainability of those host communities that depend on tourism activity (Patterson, Bastianoni \& Simpson, 2006; Viner, 2006). Indeed, Australia is vulnerable to many of the impacts of climate change including rising sea levels, warmer temperatures, changing rainfall and storm patterns and greater fire risks (Commonwealth Department of Climate Change, 2008). The IPCC Fourth Assessment Synthesis Report (IPCC, 2007) predicts that the impacts of climate change in Australia will manifest in terms of: significant loss of biodiversity by 2020 in some ecologically rich sites including the Great Barrier Reef and Queensland Wet Tropics; intensified water security problems; by 2030, production from agriculture and forestry is projected to decline; and, by 2050, increases in the severity and frequency of storms and coastal flooding, in conjunction with ongoing coastal development and population growth in some areas of Australia, are projected to exacerbate the risks from sea level rise. Indeed, in 2011 Australia has seen many extreme weather events and natural disasters which have heightened concerns (in some circles) regarding impending climate change. These events have highlighted that climate change is a threat to Australia's natural, built and socio-cultural environment. For instance, climate change is recognised as the greatest long term threat to one of Australia's most iconic tourist destinations, the Great Barrier Reef, which generates $\$ 1.5$ billion annually from tourism (Forsyth, Dwyer \& Spurr, 2007; IPCC, 2007). As the Great Barrier Reef Marine Park Authority (2009) have noted, the future health of the reef and the sustainability of its tourism industry are inextricably linked, and both are vulnerable to climate change. 
Australia's predicament is not unique, and many countries, and tourism sectors, in the Asia Pacific region face similar or far worse scenarios. However, the tourism industry has been criticised for its 'short sightedness' and lack of action regarding climate change (Hall \& Higham, 2005; Jenkins \& Nicholls, 2010; Viner, 2006). In fact, little empirical research has been undertaken on the tourism industry's (that is, the businesses and organisations in the tourism supply chain) viewpoints and perspectives regarding climate change and importantly, the strategies and actions required by the tourism industry to facilitate adaptation and mitigation strategies (Gössling \& Peeters, 2007). With a recent exception (see Turton, Dickson, Hadwen, Jorgensen, Pham, Simmons, Tremblay \& Wilson, 2010) research has also yet to explore the Australian tourism industry's perspectives on current challenges and future directions with regards to climate change. Given this context, this paper presents the findings of a qualitative study undertaken with expert representatives from both the public and private sectors of Australia's tourism industry. In-depth, semistructured telephone interviews were conducted with a sample of federal, state and local tourism industry representatives with the objectives of exploring:

1. current perceptions of, and responses to, the impacts of climate change on tourism;

2. the relative importance of immediate action for climate change vis-à-vis other challenges facing the sector; and,

3. the appropriateness of government policies and initiatives for tourism and climate change and the impacts of these on the tourism industry.

\section{Literature Review}

Climate change has been characterised by a divide between the science and the sceptics, with the United Nations Framework Convention on Climate Change ([UNFCCC], 1992, Article 
1) defining climate change as "a change of climate which is attributed directly or indirectly to human activity that alters the composition of the global atmosphere and which is in addition to natural climate variability observed over comparable time periods". Increasingly though, there seems to be broader acceptance of the occurrence and implications of global warming and environmental change. In tourism, current research supports the science with fairly widespread agreement that tourism is both a contributor to, and potential casualty of, climate change. Indeed, acknowledging that climate is a key resource for tourism and that the sector is highly sensitive to the impacts of climate change, the Davos Declaration (UNWTO, UNEP \& WMO, 2008) urged action by the entire tourism sector to face climate change, noting climate change is one of the greatest challenges to sustainable tourism development.

Much of the existing research in tourism has acknowledged the sensitivity of the sector to changing climatic conditions at the tourism destination; attributable to the fact that the destination's climate is one of the most important factors in a traveller's decision-making process (Agnew \& Palutikof, 2006; Amelung, Nicholls \& Viner, 2007; Bigano, Hamilton \& Tol, 2006; de Freitas, 2003; de Freitas \& Matzarakis, 2007; Hamilton \& Lau, 2006), while also defining the timing, length and quality of tourism seasons (Hamilton \& Lau, 2006; Lise \& Tol, 2002; Scott, Gössling \& de Freitas, 2009). Suffice to say that since the environment and climate conditions of a destination are often the key attraction and basic resource for tourism, adverse climate conditions can seriously harm tourism operations and the sustainability of host communities that depend on tourism activities (Patterson et al, 2006; Viner, 2006). As such, it has been said that tourism is a climate sensitive economic sector 
(Bartels, Heinrichs, Barth, Kreilkamp \& Moeller, 2007; Endler, Oehler \& Matzarakis, 2009; Gössling \& Hall, 2006; Scott \& Jones, 2006).

There now exists a general consensus amongst scientists that an increase of $2^{\circ} \mathrm{C}$ in global temperatures would amount to a threshold above which irreversible and potentially cumulating impacts would occur (IPCC, 2007a; Stern, 2006). Such a rise in global temperature would make current popular sun, sea and sand tourist destinations such as Australia too hot, while colder climate tourist destinations with ski tourism will also lose their appeal due to low levels of snow fall and a shorter winter season. Coastal tourism destinations are threatened by sea level rises, as are small islands. As Wall (1996: 210) has noted, "rising sea levels may...threaten the[ir] very existence".

While the likely impacts of climate change on the tourism sector are becoming clearer, and providing guidance for adaptation, the full implications of mitigation strategies are less certain. For instance, Prideaux (2009) acknowledges that there will inevitably be policies and investments to reduce GHG emissions, such as carbon taxes. Such systems will surely impact on tourist flows and mobility, operator costs and destination competitiveness (Dwyer, Edwards, Mistilis, Roman \& Scott, 2009; Gössling, Peeters \& Scott, 2008; Simpson, Gössling, Scott, Hall \& Gladin, 2008), particularly for long haul destinations such as Australia which will become more expensive. Similarly, tourism dependent nations have expressed concern over mitigation policies and the impacts on the cost of travel and subsequent tourism demand (Gössling et al, 2008). 
Few would argue that tourism does not have a range of economic, social and environmental consequences. With continued growth in international tourist arrivals expected, and $5 \%$ growth in air travel until 2020 (Gössling \& Peeters, 2007), climate change has renewed the focus on the sustainable development of the sector. Yet, the tourism sector is often criticised for its lack of strategic direction and long-term planning and increasingly concern is being expressed over the industry's response to, and preparedness for, the impacts of climate change (Bartels et al, 2007; Gössling \& Peeters, 2007; Turton et al, 2010; Viner, 2006). For instance, Bartels et al (2007) find that tourism entrepreneurs continue to be focused on short term decision-making and that climate change is not integrated adequately into strategic planning and management procedures. Nicholls (2004) attributes this to the fact that many policy makers and small-to-medium sized tourism businesses tend to work in short term time frames focused on profitability, while most climate change scenarios are proposed for the next decade to century. Further, scepticism continues to be a contributing factor. For instance, Scott \& McBoyle's (2007) study of the ski tourism sector found that operators are not willing to invest in something that may not eventuate. As such, authors such as Matteuci and Lund-Durlacher (2008) claim that more attention should be given to investigating the perceptions and strategies of tourism industry managers. Certainly in Australia this is an under researched area (see Turton et al, 2010). Therefore, a study was undertaken to explore the Australian tourism industry's perspectives of current challenges and future directions with regards to climate change.

\section{Methodology}

A qualitative methodology, utilising the content analysis thematic framework approach, was employed to address the research objectives of the study. In-depth, semi-structured 
telephone interviews were conducted with a sample of tourism industry representatives to explore: (1) current perceptions of, and responses to, the impacts of climate change on tourism; (2) the relative importance of immediate action for climate change vis-à-vis other challenges facing the sector; and, (3) the appropriateness of government policies and initiatives for tourism and climate change and the impacts of these on the tourism industry. An interview guide was developed through an analysis of pertinent themes in the literature.

Given the exploratory nature of the research, 'expert' interviews were undertaken with representatives of the Australian tourism industry. Interviewing industry experts are appropriate for qualitative studies, such as this one, where it is not feasible to survey large samples of the population. Importantly, expert interviewing is not only timely and effective for exploratory research, but experts tend to have strong insights in aggregated and/or specific knowledge, they are often networked persons and they have privileged access to information about groups of persons or decision processes (Audenhove, 2007). Due to the focus of the research, expert participants were selected that could meet these criteria and confidently and adequately discuss current perceptions and practices regarding climate change within the Australian tourism industry. Like Turton et al (2010) it was important that participants could provide informed discussion on current and future trends on behalf of the sector. For this study it was deemed that representatives from National and State Tourism Organisations and Tourism Industry Councils would be the most appropriate experts to include in the study.

Through a purposive sampling strategy (Jennings, 2001) a total of 19 telephone interviews were undertaken with representatives from Commonwealth government tourism 
departments $(n=2)$ (code Federal); State tourism organisations and associations $(n=8)$ (code State) and both federal and state tourism industry councils $(n=9)$ (code Industry) over a three month period in 2009 . This represented a cumulative response rate of $82 \%$. Each of the expert participants were senior members of their organisation and included Chief Executive Officers, Directors, Managers and Senior Policy Analysts. Other participants were employed in climate change and/or sustainable development divisions/roles within their respective organisation. Interviews were undertaken with representatives from each of the eight States and Territories in Australia. It was also found that saturation point had been reached in terms of identifying additional appropriate experts to participate in the study based on the sampling method employed.

There are several limitations of the study and one of these was that only industry representatives were surveyed. Such respondents are arguably more aware of climate change issues due to their positions in government, access to information and other resources. Unquestionably, surveying industry operators themselves could have uncovered a range of other issues. Further, this study was exploratory and so a relatively small sample was obtained; although arguably acceptable for a qualitative study where saturation point has been reached in sampling.

Interviews were conducted via telephone due to budget constraints and the dispersal of participants around the country. While there are limitations of telephone interviewing (Creswell, 1998; James \& Busher, 2006; Sturges \& Hanrahan, 2004), the benefit of the technique for this research was that it allowed for access to hard to reach respondents. As Sturges and Hanrahan (2004: 109) note, "telephone interviewing may provide an 
opportunity to obtain data from potential participants who are reluctant to participate in face-to-face interviews or from groups who are otherwise difficult to access in person". Accessing senior representatives of organisations for prolonged interviews is a challenge, and telephone interviewing offers flexibility and convenience for the participant. All telephone interviews were recorded with the permission of the interview participant, and transcribed verbatim. Member cross-checking was employed prior to data analysis. Typically interviews did not exceed 30 minutes, depending on respondents' willingness to discuss and delve into the issues under investigation.

Content analysis was employed to analyse the interview transcripts and thematic coding techniques were utilised. This approach involves organizing the data into categories on the basis of themes, concepts or similar features, from which new concepts are developed, conceptual definitions are formulated, and relationships among concepts are examined (Berg, 2001; Jennings, 2001; Miles \& Huberman, 1994; Neuman, 2000). Identified themes, concepts and patterns are then considered in light of previous research and theories, so that generalizations can be established (Berg, 2001). This constant comparative method requires the comparison of all the items of data that have been assigned to the same category, with the aim being to clarify what the categories that have emerged mean, as well as to identify sub-categories and relations among categories (Berg, 2001). The benefit of this approach is that it provides a useful method for organizing the content according to some characteristics prior to the application of the next level of data coding (Baker, 1999). This approach also avoids the more quantitative content analysis practice of counting words and paragraphs. 
A final limitation of the study was that there may be some bias in the results due to the nature of the research issue. As McKercher, Prideaux, Cheung and Law (2010) have noted, environmental issues are so infused politically and socially that people may feel compelled to give the "right" answer, even if it may not be an honest response. This could arguably be the case with climate change, although the use of industry representatives may have overcome this to some extent.

\section{Results and Discussion}

\section{Perceptions of climate change}

While the tourism industry may lack strategic and long term directions for climate change (Bartels et al., 2007; Turton et al, 2010), in the Australian context this is certainly not due to a lack of awareness of the issue. All survey respondents acknowledged that climate change is an issue that the tourism industry is conscious of; "there is certainly awareness of the carbon footprint that international visitors in particular have when they travel to Australia" (Industry). Respondents acknowledged that industry will eventually need to respond to climate change because of its potential impacts on consumer demand and travel purchasing patterns (Figure 1); "it's a global thing in that it affects people's potential travel patterns, their choices of places where they may stay and how they might go about their travel" (State). Changing consumer demand patterns for long-haul destinations in particular was an issue that many of the respondents were very aware of; "so our businesses will be impacted by the number of people who will be able to come to Australia...we don't know how much, but we know that there will be some people who will choose not to come to Australia" (State) and "the impact on consumer behaviour and the growing awareness of the impact on long-haul way of travel and stuff like that which we're probably not yet to see a whole lot of 
change but certainly within Europe I think there's a tendency or a shift to more short-haul travel" (Industry).

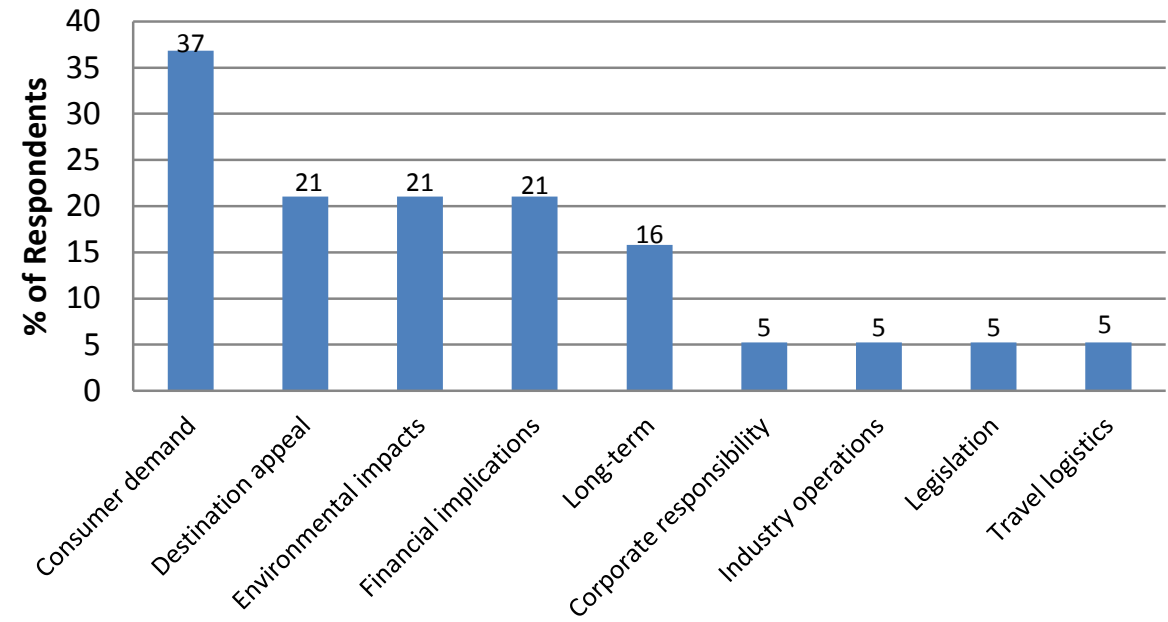

Figure 1: The impacts of climate change on the Australian tourism industry

Aside from consumer demand, Australia's appeal as a destination was also concerning for respondents and seen as an issue that will impact on the tourism industry. For instance, the prediction that changing weather patterns may alter Australia's favourable climate was cited as an example of how climate change can impact on Australia's appeal as a destination; "we also trade on our weather - in general people want good weather for their holiday... that is included in the holiday making decision" (State). Similarly, environmental impacts were seen as closely linked to destination appeal. Many of these respondents discussed the potential of Australia's natural attractions being degraded through climate change; "natural assets that are a big part of Australia's attraction and it's rather obvious that climate change is going to have a big impact on those" (Industry).

Some respondents recognised the impacts for operators whose product is dependent on the natural environment; "tourism is so reliant, particularly in Australia on the natural 
environment, and as such any changes in the natural environment, are going to have a significant impact on how the tourism industry can operate" (Federal). As one respondent stated, "some operators are very concerned about the natural areas in which they operateparticularly coastline and bushfire prone wilderness areas" (State). Parts of the country that are seen as threatened include: "the Barrier Reef, rainforests of North Queensland and many coastal areas are very susceptible to the impacts from climate change" (Federal), and "...is certainly a huge risk for the future of Australian tourism industry currently how it operates, given places like Kakadu, Great Barrier Reef, Margaret River, you know, all these Australian icons. Certainly there's a big questions mark over the future regarding those" (Industry). Similarly, in Turton et al's (2010) study, survey respondents' concerns tended to revolve around tourist and investor perceptions of the risk for their destination from climate change's impacts.

Respondents also noted the financial implications for the tourism industry associated with climate change (Figure 1); "there are some tougher longer term decisions that need to be made that aren't always going to be in the financial interests of the business" (State). Financial implications were raised, both in terms of the costs of running a business, but also the impact on consumers. As one respondent noted, "so our businesses will be impacted by the number of people who will be able to come to Australia, possibly - we don't know how much, but we know that there will be some people who will choose because of price sensitivity not to come to Australia" (State). Other respondents were concerned about future measures to address climate change for instance, "obviously if there are financial implications for things like carbon pollution, trading schemes etcetera..." (State) and "also we're concerned that some of the policies that are measured to ameliorate the impacts on 
climate change will impact the cost effectiveness of our industry" (Industry). Some respondents noted that Australia's tourism industry will be impacted upon by external actions; "of course with legislation that's occurring in Europe and in the UK with taxation and environmental policies with $\mathrm{CO} 2$ emissions...the appeal of Australia or long haul destinations will also have the capacity to be affected" (Industry).

\section{Climate change vis-à-vis other industry challenges}

Previous studies have shown that climate change is often viewed as a long-term issue. For instance, as Jenkins and Nicholls (2010) noted, many policy makers and small-to-medium sized tourism businesses tend to work in short term time frames focused on profitability, while most climate change scenarios are proposed for the next decade to century (Nicholls, 2004). As Scott \& McBoyle (2007) noted, the long term orientation of climate change meant that tourism operators are not willing to invest in something that may not eventuate. Given this context, the relative importance of climate change was explored, with respondents questioned on whether climate change was in fact a current issue or concern for the Australian tourism industry (Figure 2). Although most respondents identified likely impacts of climate change on the Australian tourism industry, the majority believe that to date, the Australian tourism industry has yet to experience any impacts of climate change; "as far as whether the industry has been affected through a change in visitation; I would say no at this stage" (State). This contrasts quite dramatically with the findings of the few tourism industry studies that have been undertaken to date. For instance, Valls and Sarda (2009) found that almost $80 \%$ of tourism 'experts' in Mediterranean believed that climate change impacts had already begun and were being experienced. Similarly, Jenkins and Nicholls (2010) found that business operators in Torbay, England already believed they were being 
affected by climate change through changing seasonality, increased storm frequency and intensity and flooding. As a result, nearly $70 \%$ of businesses had already implemented, or plan to implement, some form of adaptation measures. They added the caveat though, that those businesses that have not yet witnessed any changes were less concerned or willing to change their behaviour. Respondents in the current study did note that while the physical impacts of climate change were not yet being experienced they did note some changes to consumer behaviour. For instance, several respondents did note that there had been some minor changes in consumer expectations regarding the environmental practices of businesses; "well they expect to find recycling bins wherever they need one. They expect to find low flow showerheads. They expect to find more of the kind of normal, relatively easy changes that people have made...they'll be shocked that they can't find a recycling bin" (State).

While most respondents believe that the impacts of climate change are not yet evident, concurrent with assertions made in the literature, many respondents attribute this to the fact that climate change is something that will potentially affect tourism in the future; "well it has the potential to affect the industry...any visitor experience that's available from immersing yourself in the natural setting and seeing amazing scenery and plants and animals and all the diversity of life around here is under threat as a result of impact from climate change" (Federal). However, the conclusion drawn from Scott \& McBoyle's (2007) study was that because the impacts are not yet being felt, climate change adaptation in the ski industry is likely to remain reactive. They note little evidence of long-term, forward business planning in anticipation of future changes in climate. Encouragingly in the current study, although climate change is seen as a longer term issue, several respondents did 
discuss adaptation research that was currently being undertaken in Australia for the tourism industry; "...worked with the Great Barrier Reef Marine Park Foundation structuring research projects for the future and we're working with the Great Barrier Reef Marine Park Authority and the industry itself of course and we've recently... released an action plan for climate change for marine park operators" (Industry). Additionally, several respondents discussed an increased focus on 'best practices'; "we're seeing more and more of our tourism businesses seeking things like accreditation...so more and more businesses are a) interested in the issue and b) are taking some action; taking some steps to deal with the issue" (Industry) and "they want to make sure that their businesses are kept at best practice, working very hard to ensure that they're measuring their carbon emissions, their water use" (Industry).

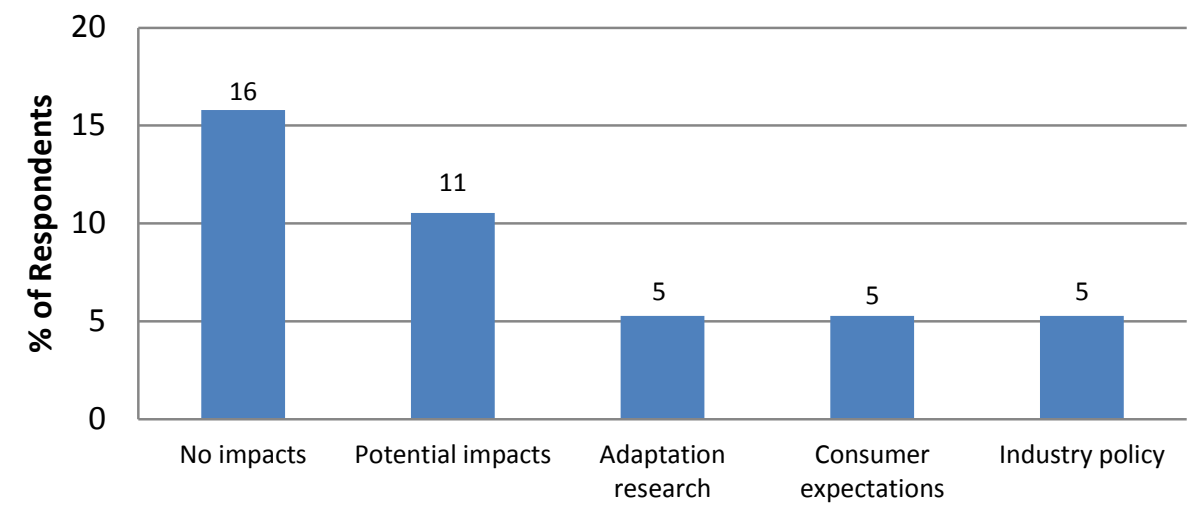

Figure 2: The current importance of climate change for the Australian tourism industry

In terms of the second research objective, that is, the relative importance of climate change vis-à-vis other challenges facing the tourism industry (Figure 3), the responses received somewhat conflicted previously outlined industry sentiments that climate change is a longterm or 'potential' concern. For instance, climate change was identified as the second most 
important current issue for the Australian tourism industry by respondents. For most respondents, climate change had taken second place to financially surviving the global financial crisis and economic downturn in Australia; "the broader global financial crisis and the issues that's had on the tourism industry, probably does have a similar or if not a greater impact" (State) and "it's not their number one concern...the costs and the financial situation at the moment...are probably more pressing at this point in time" (Industry). For other respondents, the 'traditional' concerns of the tourism industry such as product development and market demand were still considered to be the most important issues for the tourism industry; "I think the ongoing issues of ensuring strong levels of demand for your product and for the destination, ensuring that we're meeting the market appropriately, ensuring we've got adequate access and supply of things like hotel rooms, I think are probably the more pressing issues" (Industry).

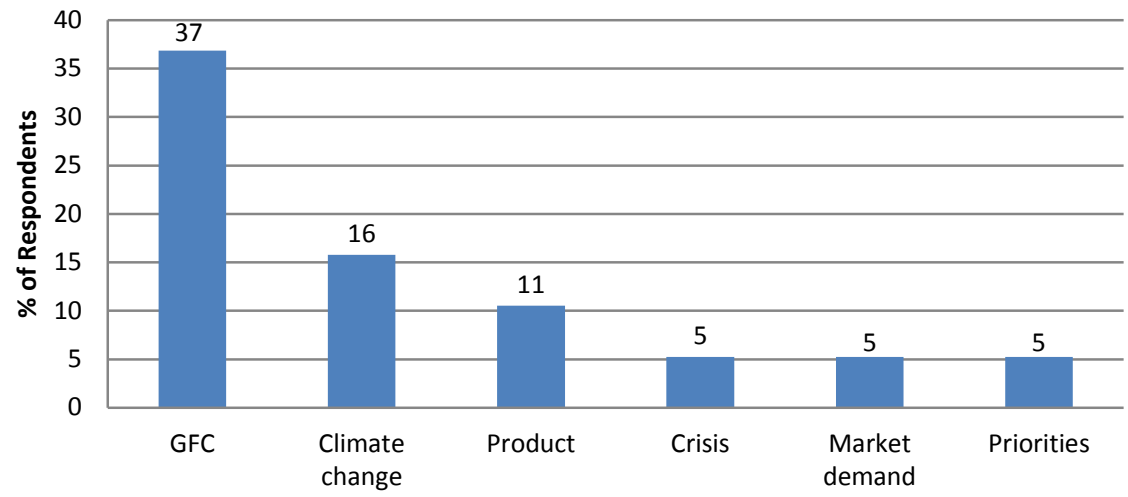

Figure 3: The current most important issue for the Australian tourism industry

\section{Climate change policy}

In response to the final research objective, the appropriateness of government policies and initiatives for tourism and climate change, respondents were asked to identify what the 
tourism industry requires in terms of support for climate change adaptation and/or mitigation strategies. While some respondents stated; "we haven't really quantified, as yet, exactly what tourism needs to do as an industry by itself in the area of adaptation" (State), overwhelmingly the vast majority of respondents discussed the need for education strategies for the tourism industry; "I think the need to understand the issue is probably one part of it then actually adapting to it is another part. I think there's still a lot of education that needs to be undertaken in that regard" (Industry) and "I think that if it was more widely known, accepted, understood what the effects of climate change could be on this industry in Australia, then I think there would be greater concern and people would start acting accordingly" (State). Respondents also consider a need for education in particular sectors of the industry; "for accommodation providers to deal with the impacts of changes to weather patterns, the impact of changes to severe weather events" (Industry).

The findings of this study show that the Australian tourism industry is primarily looking to government to provide assistance in terms of climate change. This concurs with the findings of Turton et al (2010) who also noted the industry's reliance on the government for leadership on climate change adaptation. As one respondent in the present study noted, the government has a responsibility to educate the sector on climate change; "the policymakers have a responsibility to actually provide clear information, because people in the tourism industry, and any industry, are quite confused by the amount of noise that's out there about this issue and the conflicting opinions" (State). The need for government funding was also frequently cited and respondents noted that the industry generally expects the government to support the industry in responding to climate change; "...if there were still some opportunities for businesses to get maybe dollar-for-dollar funding to change old 
whitegoods or to install new technologies such as new engines in their boats that would enable them to use a bio-fuel instead of a diesel" (Industry) and "funding to assist in implementation of an action plan would be very good" (Industry).

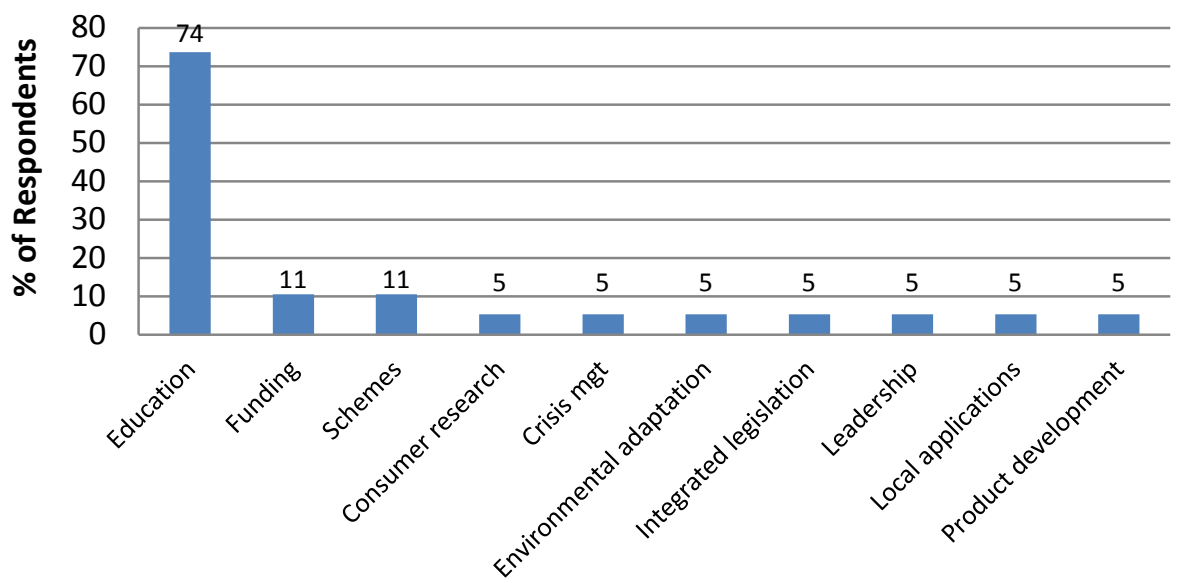

Figure 4: Government support for the tourism industry to respond to climate change

Finally, respondents were asked what they consider to be the next steps for the tourism industry in terms of responding to climate change. Again, contradictory to respondents' suggestions that climate change was a long term issue, most respondents identified the need for action on climate change and tourism. As one respondent noted, "addressing climate change from a tourism perspective or assistance for industry, it's taken largely a back seat" (State). Again, funding was identified as inhibiting action; "well obviously with more money more could be done" (Industry) and "within the resource capacities of [organisation] it's probably the best we can do at the moment. Ideally if we had greater funding then probably yes we could do more" (State). The need for strategic direction and governance was identified by several respondents; " $a$ lot more work to be done and we need to further develop our strategies and our policies in this field" (Federal). Other respondents 
noted the need for legislation and policy; "there's a long way to go still in the policy debate and in really concrete actions that need to be taken" (State).

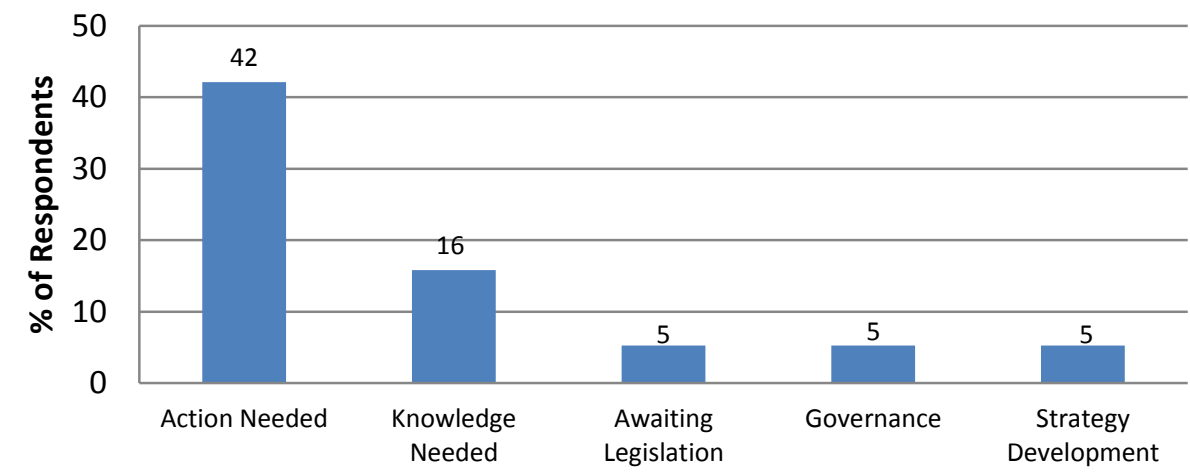

Figure 5: Actions needed for the tourism industry to respond to climate change

\section{Conclusions}

In spite of calls for action on climate change generally, and in tourism specifically (UNWTO, 2007), this study has shown that the Australian tourism industry is largely operating in 'business as usual' mode. The long-term nature of climate change is largely the reason for the lack of current action and uncertainty is prohibiting the development of proactive initiatives. Arguably criticisms of the tourism industry for its 'short sightedness', due to short term financial objectives (Hall \& Higham, 2005; Jenkins \& Nicholls, 2010; Viner, 2006) appear warranted. Some attribute this to the high proportion of SMEs in the tourism industry that operate on smaller overheads, shorter planning timeframes and little or no capital or capacity to implement major adaptation strategies (Scott \& McBoyle, 2007; Turton et al, 2010). As Turton et al (2010: p.441) note, "very few SMEs are able to plan on time frames longer than a couple of years, and as a result, making changes now, which will 
cost something, with a view to threats that may or may not eventuate in 10,20 or 50 years time is not something that many of these smaller operators are willing (or able) to do".

The tourism industry's lack of action, or response to climate change issues, is consistent with some studies on consumers and their responses to climate change. Like this study, McKercher et al (2010) found that few tourists have changed or appear to be willing to change their behaviour voluntarily in response to climate change concerns. They noted the contradiction as most tourists were aware of the dangers posed by climate change and recognised the need to act. Yet, most people were unwilling to translate their concerns into meaningful personal actions by voluntarily changing their own consumption patterns generally, and travel decisions in particular. McKercher et al concluded that there was little demand-side interest in modifying travel, especially among those who travel the most, and suggested that as there is currently little acceptance of the need to change, legislated options will become more likely. A lack of supply side initiative regarding climate change is also likely to lead to government intervention through legislation. In fact, this is something that, according to respondents, the industry is waiting upon. In effect, relinquishing the opportunity to be proactive in the development of industry-driven and industry-led mitigation strategies.

The uncertainties surrounding the full implications of climate change were cited by many respondents and seen as justifying the lack of action. Like Turton et al's (2010) study, the tourism sector is not yet ready to invest in climate change adaptation because of the perceived uncertainties. This was also the conclusion drawn from Scott \& McBoyle's (2007) study of ski tourism operators who displayed a lack of long term orientation and an 
unwillingness to invest in something that may not eventuate. As such Turton et al (2010) concluded that the adoption of new practices will be linked to:

- confidence that the climate is really changing and that increased variability in climate is part of the process.

- motivation to avoid risk or take up opportunities.

- demonstration of new technologies.

- transitional support from the government.

- effective monitoring and evaluation.

The findings of this study suggest that, as noted, the Australian tourism industry is currently at the stage of expecting transitional support from government. According to respondents the tourism industry is generally unwilling to change their business practices until forced to do so by some external force such as regulators or price. As McKercher et al (2010), in their conclusions on consumer change noted, "most people find it difficult to implement major lifestyle changes on a voluntary basis although when compelled by external agents will usually comply with little dissent" (p.301). It seems as though the industry is set to follow this path also.

Another option is that the impacts of climate change will force the tourism industry to take action. According to Richins and Scarinci (2009) in Florida the potential impacts of climate change have provided the impetus for many hotels to renovate to meet the criteria of "Green Lodging" hotels. Indeed the previously mentioned case of Torbay, England where industry perceive the impacts of climate change to already be experienced have caused $70 \%$ of operators to implement, or plan to implement, some form of adaptation measures. The 
crux of Jenkins and Nicholls' (2010) finding in that study was that businesses that have not yet witnessed any changes were less concerned or willing to change their behaviour. This can explain the current approach, or lack of, by the Australian tourism industry. Changing climatic and environmental conditions or disasters such as cyclones, floods and bushfires, can be linked to other factors and are not necessarily attributed to climate change. The enormity of climate change may be contributing to avoidance or even ignorance; 'turning a blind eye' is likely common practice. Certainly this could be an issue to explore in future research. Additionally, Turton et al (2010) found that respondents perceived there to still be enough scepticism in the community regarding climate change to prohibit rapid and significant adaptation. Arguably scepticism still proliferates in Australia, even amongst Federal government. The federal opposition leader is a renowned sceptic and has been quoted as saying that climate change is "absolute crap [sic]", although has since refined his stance to, "it is an open question how much the climate changes today and what role man plays" and "man contributed to climate change, but there's an argument as to how great that contribution was and what should be done about it" (Morton, 2010). In Australia, climate change has been a political issue; the signing of Kyoto which only took place in 2008 following a change of government leadership; political party leadership spills over climate change stances; and the contentious issue of carbon taxes which is being deliberated yet again.

Government leadership is crucial. While the industry should be taking some initiative, Frey (2010) notes that perceptions by tourism businesses of lacking government support has to be changed. It is imperative that the private sector believes in the competence and will of government to bring about change. If government won't show leadership than operators 
are likely to continue their business as usual approach. However, the present lack of action only succeeds in increasing the future vulnerability of tourism businesses (Jenkins \& Nicholls, 2010). Future research should focus in this area and there is much scope to increase capacity of operators, government and other stakeholders. Arguably there is much to do in terms of education and knowledge dissemination.

To conclude on a somewhat positive note, increasing numbers of businesses are realising that green sells. While greenwashing should be avoided, and dispelled, at all costs, green marketing is one approach that might enhance the tourism industry's capacity to better position itself in a climate-change-affected marketplace (Turton et al, 2010). There have also been more businesses seeking accreditation and so the environmental practices of businesses are coming under more scrutiny. Arguably though, this could be linked to sustainable development generally rather than climate change specifically. As Scott and Becken (2010) noted, most change within the tourism sector can be achieved when businesses get involved. More and more tourism businesses are recognizing the benefit of saving energy and there are growing numbers of businesses implementing such initiatives. Where initiatives will reward the business with tangible benefits such as cost savings or risk reduction, or can be used in marketing for competitive advantage, there will be continue to be opportunities amidst growing interest in sustainable and environmentally friendly holidays (Jenkins \& Nicholls, 2010; Scott \& Becken, 2010). For researchers, this represents an area with scope for considerable further investigation. 


\section{References}

Agnew, M. \& Palutikof, J.P. (2006). Impacts of short-term climate variability in the UK on demand for domestic and international tourism. Climate Research, 31(1), 109-120.

Amelung, B., Nicholls, S. \& Viner, D. (2007). Implications of global climate change for tourism flows and seasonality. Journal of Travel Research, 45(3), 285-296.

Audenhove, L.V. (2007). Expert interviews and interview techniques for policy analysis. Available at: http://www.ies.be/files/060313\%20Interviews VanAudenhove.pdf

Baker, T.L. (1999). Doing Social Research (3 ${ }^{\text {rd }}$ edn). Boston: McGraw-Hill.

Baker, W.M. \& Olsson, L.E. (1992). Tourism: A climate-sensitive industry. UNEP Industry and Environment, 15(3), 9-16.

Bartels, C., Barth, M., Heinrichs, H., Kreilkamp, E.A.M. \& Moeller, A. (2007). Tourism strategies for adaptation and sustainable development in mountain and coastal destinations in Germany. Paper presented at the 3rd International Workshop on Climate, Tourism and Recreation: Developments in Tourism Climatology, Alexandroupolis, Greece.

Berg, B.L. (2001). Qualitative Research Methods for the Social Sciences ( $5^{\text {th }}$ edn). Boston: Allyn and Bacon.

Bigano, A., Hamilton, J. \& Tol, R. (2006). The impact of climate change on domestic and international tourism: A simulation study. Lecce: Centro Euro-Mediterraneo per $\mathrm{i}$ Cambiamenti Climatici.

Commonwealth Department of Climate Change (2008). Carbon Pollution Reduction Scheme: Green Paper. Canberra: Commonwealth of Australia.

Craig-Smith, S. \& Ruhanen, L. (2005). Implications of climate change on tourism in Oceania. In C. M. Hall \& J. Higham (Eds.), Tourism, Recreation and Climate Change (pp. 181191). Clevedon: Channel View Publications.

Creswell, J.W. (1998). Qualitative Inquiry and Research Design: Choosing Among Five Traditions. Thousand Oaks, CA: Sage.

de Freitas, C.R. \& Matzarakis, A. (2007). Sensitiviy of thermal conditions for tourism to climate change and variability: A comparion of regional scale case studies. Paper presented at the 3rd International Workshop on Climate, Tourism and Recreation: Developments in Tourism Climatology, Alexandroupolis, Greece.

Dwyer, L., Edwards, D., Mistilis, N., Roman, C. \& Scott, N. (2009). Destination and enterprise management for a tourism future. Tourism Management, 30(1), 63-74.

Endler, C., Oehler, K. \& Matzarakis, A. (2009). Vertical gradient of climate change and climate tourism conditions in the Black Forest. International Journal of Biometeorology, 51(1), 45-61.

Forsyth, P., Dwyer, L. \& Spurr, R. (2007). Climate Change and Australian Tourism. Gold Coast: Sustainable Tourism Cooperative Research Centre.

Frey, N. \& George, R. (2009). Responsible tourism management: The missing link between business owners' attitudes and behaviour in the Cape Town tourism industry. Tourism Management, 31(5), 621-628.

Gössling, S. \& Hall, C. M. (2006) (Eds.). Tourism and Global Environmental Change: Ecological, Social, Economic, and Political Interrelationships (pp. 229-250). New York: Routledge.

Gössling, S. \& Peeters, P. (2007). 'It does not harm the environment!' An analysis of industry discourses on tourism, air travel and the environment. Journal of Sustainable Tourism, 15(4), 402-417. 
Gössling, S., Peeters, P. \& Scott, D. (2008). Consequences of climate policy for international tourist arrivals in developing countries. Third World Quarterly, 29(5), 873-901.

Great Barrier Reef Marine Park Authority (2009). Great Barrier Reef: Climate Change Action Strategy 2009-2012. Townsville: Great Barrier Reef Marine Park Authority.

Hall, C.M. \& Higham, J. (2005) (Eds.). Tourism, Recreation and Climate Change. Clevedon: Channel View Publications.

Hamilton, J.M. \& Lau, M.A. (2006). The role of climate information in tourist destination choice decision-making. In S. Gössling \& C. M. Hall (Eds.), Tourism and Global Environmental Change: Ecological, Social, Economic, and Political Interrelationships (pp. 229-250). New York: Routledge.

Intergovernmental Panel on Climate Change (2007). Summary for Policy Makers. Geneva: Intergovernmental Panel on Climate Change.

Intergovernmental Panel on Climate Change (2007a). Climate Change 2007: Synthesis Report. Geneva: Intergovernmental Panel on Climate Change.

James, N. \& Busher, H. (2006). Credibility, authenticity and voice: Dilemmas in online interviewing." Qualitative Research, 6(3), 403-420.

Jenkins, K. and S. Nicholls (2010). The impacts of climate variability and potential climate change on tourism business in Torbay, England and implications for adaptation. Tourism Analysis, 15(1), 17-30.

Jennings, G. (2001). Tourism Research. Milton: John Wiley \& Sons.

Lise, W. \& Tol, R.S.J. (2002). Impact of climate on tourist demand. Climate Change, 55(4), 429-449.

Matteuci, X. \& Lund-Durlacher, D. (2008). Tourism professionals' attitudes towards climate change and their strategies to respond to global warming. Paper presented at BEST EN Think Tank VIII Sustaining Quality of Life through Tourism, Izmir, Turkey.

McKercher, B., Prideaux, B., Cheung, C. \& Law, R. (2010). Achieving voluntary reductions in the carbon footprint of tourism and climate change. Journal of Sustainable Tourism, 18(3), 297-317.

Miles, M. \& Huberman, M.A. (1994). Qualitative Data Analysis: An Expanded Sourcebook $\left(2^{\text {nd }}\right.$ edn $)$. Thousand Oaks: Sage.

Morton, J. (2010). Climate scientists cross with Abbott for taking Christ's name in vain. Sydney Morning Herald, May $10 . \quad$ Available at: http://www.smh.com.au/environment/climate-change/climate-scientists-crosswith-abbott-for-taking-christs-name-in-vain-20100509-ulqt.html

Neuman, W.L. (2000). Social Research Methods: Qualitative and Quantitative Approaches $\left(4^{\text {th }} \mathrm{edn}\right)$. Boston: Allyn and Bacon.

Nicholls, S. (2004). Climate change and tourism. Annals of Tourism Research, 31(1), 238-240.

Patterson, T., Bastianoni, S. \& Simpson, M. (2006). Tourism and climate change: Two-way street, or vicious/virtuous circle? Journal of Sustainable Tourism, 14(4), 339-348.

Prideaux, B. (2009). Resort Destinations: Evolution, Management and Development. Oxford: Butterworth-Heinemann.

Richins, H. \& Scarinci, J. (2009). Climate change and sustainable practices: A case study of the resort industry in Florida. Tourismos, 4(2), 107-128.

Scott, D. \& Becken, S. (2010). Adapting to climate change and climate policy: Progress, problems and potentials. Journal of Sustainable Tourism, 18(3), 283-295.

Scott, D., Gössling, S. \& de Freitas, C.R. (2009). Preferred climates for tourism: Case studies from Canada, New Zealand and Sweden. Climate Research, 38(1), 61-73 
Scott, D. \& Jones, B. (2006). Climate Change and Seasonality in Canadian Outdoor Recreation and Tourism. Waterloo: Univsersity of Waterloo.

Scott, D. \& McBoyle, G. (2007). Climate change adaptation in the ski industry. Mitigation and Adaptation Strategies for Global Change, 12(1), 1411-1431.

Simpson, M.C., Gössling, S., Scott, D., Hall, C.M. \& Gladin, E. (2008). Climate Change Adaptation and Mitigation in the Tourism Sector: Frameworks, Tools and Practices. Paris, France: United Nations Environment Programme, University of Oxford, World Tourism Organization, World Meteological Organization.

Steffen, W. (2009). Climate Change 2009: Faster Change and More Serious Risks. Canberra: Commonwealth of Australia.

Stern, N. (2006). Stern Review on the Economics of Climate Change. UK: HM Treasury.

Sturges, J.E. \& Hanrahan, K.J. (2004). Comparing telephone and face-to-face qualitative interviewing: A research note. Qualitative Research, 4(1), 107-118.

Turton, S., Dickson, T., Hadwen, W., Jorgensen, B., Pham, T., Simmons, D., Tremblay, P. \& Wilson, R. (2010). Developing an approach for tourism climate change assessment: Evidence from four contrasting Australian case studies. Journal of Sustainable Tourism, 18(3), 429-447.

United Nations Economic and Social Commission for Asia and the Pacific (2007). Study on the Role of Tourism in Socio-Economic Development. New York: United Nations.

United Nations Framework Convention on Climate Change (1992). Full Text of the Convention. Available at: http://unfccc.int/essential background/convention/background/items/1349.php

Valls, J.F. \& Sarda, R. (2009). Tourism expert perceptions for evaluating climate change impacts on the Euro-Mediterranean tourism industry. Tourism Review, 64(2), 41-51.

Viner, D. (2006). Tourism and its interactions with climate change. Journal of Sustainable Tourism 14(4), 317-415.

World Tourism Organization (2010). UNWTO World Tourism Barometer. Madrid: World Tourism Organization.

World Tourism Organization (2007). Tourism \& Climate Change: Confronting the Common Challenges. Madrid: World Tourism Organization.

World Tourism Organization, United Nations Environment Programme and World Metrological Organization (2008). Davos Declaration. In Climate Change and Tourism: Responding to Global Challenges. Madrid: United Nations World Tourism Organization; Paris: United Nations Environment Program; Geneva: World Meteorological Organization.

Wall, G. (1996). The implications of climate change for tourism in small islands. In L. Briguglio, B. Archer, J. Jafari \& G. Wall (Eds.), Sustainable Tourism in Islands and Small States: Issues and Policies (pp. 205-216). New York: Pinter Press. 